\title{
Immunobiology of mesenchymal stem cells
}

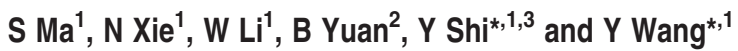

Mesenchymal stem cells (MSCs) can be isolated from almost all tissues and effectively expanded in vitro. Although their true in situ properties and biological functions remain to be elucidated, these in vitro expanded cells have been shown to possess potential to differentiate into specific cell lineages. It is speculated that MSCs in situ have important roles in tissue cellular homeostasis by replacing dead or dysfunctional cells. Recent studies have demonstrated that in vitro expanded MSCs of various origins have great capacity to modulate immune responses and change the progression of different inflammatory diseases. As tissue injuries are often accompanied by inflammation, inflammatory factors may provide cues to mobilize MSCs to tissue sites with damage. Before carrying out tissue repair functions, MSCs first prepare the microenvironment by modulating inflammatory processes and releasing various growth factors in response to the inflammation status. In this review, we focus on the crosstalk between MSCs and immune responses and their potential clinical applications, especially in inflammatory diseases.

Cell Death and Differentiation (2014) 21, 216-225; doi:10.1038/cdd.2013.158; published online 1 November 2013

Facts

- The immunoregulatory properties and the tissue reparative functions of mesenchymal stem cells (MSCs) are induced by inflammatory cytokines.

- MSCs express immunosuppressive molecules and various growth factors that facilitate tissue repair and maintain immune homeostasis.

- The plasticity of immunoregulatory roles of MSCs is relied on the inflammatory status.

\section{Open Questions}

- How do MSCs benefit patients suffering from inflammatory diseases?

- Do MSCs always possess the immunosuppressive properties?

- Does the efficiency of MSC engraftment at the injured tissue sites determine the therapeutic effects of MSCs?

\section{Properties of Mesenchymal Stem Cells}

MSCs exist in almost all tissues, and have the capacity of self-renewal and the potential to differentiate into multiple cell types. Under certain physiological and experimental conditions, MSCs differentiate into specialized cells, ${ }^{1}$ although to a lesser extent than embryonic stem cells (ES) and induced pluripotent stem cells (iPS). Nevertheless, their differentiation capacity has encouraged scientists and clinicians to seek suitable protocols to apply these cells to treat various diseases. Recently, several studies have demonstrated that MSCs can be activated and recruited to sites of tissue damage where they regenerate new tissues and repair the defects.

Stem cells bring new hope for the treatment of many diseases. The clinical use of ES or iPS cells, however, is hampered by their tendency to form teratomas, by allogeneic rejection problems and by ethical issues. In comparison with ES cells and iPS cells, MSCs are devoid of the ethical, teratomas-formation and histocompatibility issues. MSCs can be isolated from nervous tissue, adipose tissue, bone marrow, amniotic fluid, umbilical cord, placenta, menstrual blood and even dental pulps. ${ }^{2-5}$ Morphologically, MSCs have the appearance of fibroblasts. Although there is no specific marker that identifies MSCs, these cells do express certain patterns of surface markers. Because of their potent selfrenewal capacity, MSCs can be passaged many times without significant alteration of their major properties. ${ }^{6} \mathrm{MSC}$ s have the

\footnotetext{
${ }^{1}$ Key Laboratory of Stem Cell Biology, Institute of Health Sciences, Shanghai Institutes for Biological Sciences of Chinese Academy of Sciences/Shanghai Jiao Tong University School of Medicine, 225 South Chongqing Road, Shanghai 200025, China; ${ }^{2}$ National Institutes for Food and Drug Control, No. 2 Tiantan Xili, Beijing 100050, China and ${ }^{3}$ Child Health Institute of New Jersey, Robert Wood Johnson Medical School, Rutgers, the State University of New Jersey, New Brunswick, New Jersey 08901, USA

${ }^{*}$ Corresponding authors: Y Shi or Y Wang, Key Laboratory of Stem Cell Biology, Institute of Health Sciences, Shanghai Institutes for Biological Sciences of Chinese Academy of Sciences/Shanghai Jiao Tong University School of Medicine, 225 South Chongqing Road, Shanghai 200025, China. Tel: + 862163848329 ; E-mails: yufangshi@sibs.ac.cn or yingwang@ sibs.ac.cn

Keywords: mesenchymal stem cells; inflammatory diseases; immunoregulation; nitric oxide; indoleamine 2; 3-dioxygenase; engraftment

Abbreviations: MSCs, mesenchymal stem cells; ES, embryonic stem cells; iPS, induced pluripotent stem cells; EGF, epidermal growth factor; FGF, fibroblast growth factor; PDGF, platelet-derived growth factor; TGF- $\beta$, transforming growth factor- $\beta$; VEGF, vascular endothelial growth factor; HGF, hepatocyte growth factor; IGF, insulin growth factor-1; Ang-1, angiopoietin-1; KGF, keratinocyte growth factor; SDF-1, stromal cell-derived factor-1; GvHD, graft versus host disease; SLE, systemic lupus erythematosus; iNOS, inducible nitric oxide synthase; NO, nitric oxide; PGE2, prostaglandin E2; LIF, leukemia inhibitory factor; DTH, delayed-type hypersensitivity; IDO, indoleamine 2,3-dioxygenase; TSG6, tumor necrosis factor-inducible gene-6; HO-1, hemeoxygenase-1; G-CSF, granulocyte colony-stimulating factor; $\mathrm{IBD}$, inflammatory bowel diseases; $\mathrm{EAE}$, experimental autoimmune encephalomyelitis

Received 29.1.13; revised 03.10.13; accepted 04.10.13; Edited by R De Maria; published online 01.11.2013
} 
potential to differentiate into several different cell types, such as adipocytes, chondrocytes, osteoblasts, myocytes and neurons (Figure 1). ${ }^{7-11}$ These criteria are used to define cultured MSCs, however, the exact anatomical locations of these cells in situ remain unclear. Experiments to track MSCs in vivo have revealed that these cells reside mostly close to blood vessels, ${ }^{12,13}$ a trait that is similar to pericytes. Pericytes in culture are similar to cultured MSCs in term of their morphological features, cell surface markers as wells as differentiation potential into osteoblasts, chondrocytes and adipocytes. ${ }^{12,13}$ However, not all pericytes have the unique properties of MSCs and not all MSCs are equivalent to pericytes. The key distinction is that pericytes locate strictly in the basement membrane of capillary and post capillary, whereas MSCs can be isolated from interstitial tissues and tissues surrounding arteries and veins. ${ }^{14-16}$ In addition, the proposed functions of pericytes are heterogenous and varied from regulating vessel stabilization to vascular integrity and tone, which are different from the functions of MSCs. ${ }^{14}$ MSCs are involved in many physiological and pathological processes, including cellular homeostasis maintenance, aging, tissue damage and inflammatory diseases. ${ }^{1,17,18}$ Although their differentiation potential is less broad than that of ES cells and iPS, MSCs, nevertheless, hold great promise for clinical applications. The most prominent therapeutic effect of MSCs is exerted through their immunoregulatory functions. The aim of this review is to elucidate the bidirectional regulatory interactions between MSCs and immune responses. We specifically emphasize recent reports of in vitro investigations and in vivo preclinical studies that reveal the mechanisms of this MSC-immune response interaction. We also discuss their implications for the clinical uses.

\section{Communication between MSCs and Damaged Tissues}

Because of their broad tissue distribution, multipotent differentiation capacity and well-established effects in

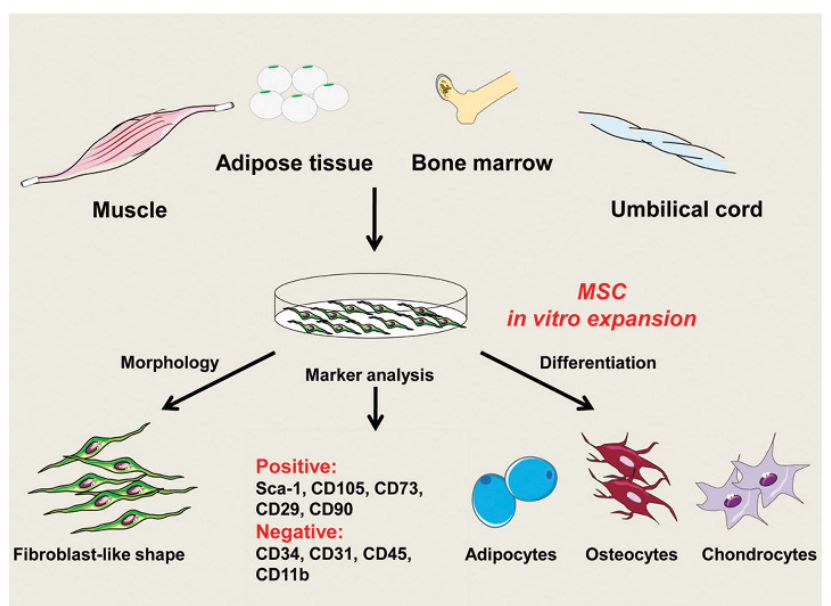

Figure 1 The properties of MSCs. MSCs can be isolated from various tissues including adipose, bone marrow, umbilical cord, muscle and tooth root. After in vitro expansion, MSCs can be defined by several characteristics. Morphologically, MSCs are fibroblast like. They also express a panel of markers: positive for Sca-1, CD105, CD73, CD29 and CD90, and negative for CD31, CD34, CD45 and CD11b. In addition, MSCs have the potential to differentiate into adipocytes, chondrocytes, osteoblasts and other cell types preclinical and clinical studies, MSCs are believed to have critical roles in repairing damaged tissues. ${ }^{18}$ Tissue injury is always associated with the activation of immune/inflammatory cells, not only macrophages and neutrophils but also adaptive immune cells, including CD4 ${ }^{+} \mathrm{T}_{\text {cells, }} \mathrm{CD}^{+}{ }^{+} \mathrm{T}$ cells and $\mathrm{B}$ cells, which are recruited by factors from apoptotic cells, necrotic cells, damaged microvasculature and stroma. ${ }^{19,20}$ Meanwhile, inflammatory mediators, such as TNF- $\alpha$, IL-1 $\beta$, free radicals, chemokines and leukotrienes, are often produced by phagocytes in response to damaged cells and spilled cell contents. ${ }^{21}$ Thus, these inflammatory molecules and immune cells, together with endothelial cells and fibroblasts, orchestrate changes in the microenvironment that result in the mobilization and differentiation of MSCs into stromal and/or replacement of damaged tissue cells. These MSCs can be tissue-resident or be recruited from the bone marrow. However, the mechanisms by which MSCs are mobilized and recruited to damaged sites are not known. In addition, how they survive and differentiate into distinct cell types is still not clear. Once MSCs have entered the microenvironment of injured tissues, many factors, including cytokines such as TNF- $\alpha$, IL-1, IFN- $\gamma$, toxins of infectious agents and hypoxia can stimulate the release of many growth factors by MSCs, including epidermal growth factor (EGF), fibroblast growth factor (FGF), platelet-derived growth factor (PDGF), transforming growth factor- $\beta$ (TGF- $\beta$ ), vascular endothelial growth factor (VEGF), hepatocyte growth factor (HGF), insulin growth factor-1 (IGF-1), angiopoietin-1 (Ang-1), keratinocyte growth factor (KGF) and stromal cellderived factor-1 (SDF-1). ${ }^{22-25}$ These growth factors, in turn, promote the development of fibroblasts, endothelial cells and tissue progenitor cells, which carried out tissue regeneration and repair (Figure 2, Table 1).

The barrier function of the endothelial monolayer in the capillary bed is often broken down in damaged tissues, allowing the release of protein-rich plasma and some leukocytes from the blood. MSCs produce various factors, like Ang-1, VEGF, HGF, EGF, PDGF, FGF, KGF and TGF- $\beta$, which directly affect endothelial cells. These paracrine trophic factors are potentially important in maintaining endothelial integrity and promoting angiogenesis through their ability to regulate endothelial cell proliferation and extracellular matrix production, reduce endothelial permeability or prevent interactions between leukocytes and endothelial cells. ${ }^{26,27}$ Apart from angiogenesis mediated by endothelial cells, in response to such trophic factors, fibroblasts also have essential functions in maintaining tissue integrity and promoting wound healing through their secretion of extracellular matrix and matrix metalloproteinase. Some in vivo studies have suggested that growth factors secreted by MSCs can be applied to improve wound healing and recovery from myocardial infarction. ${ }^{28-30}$

The long-term functional recovery of damaged tissue and organs is likely to depend on the differentiation of tissueintrinsic progenitors or stem cells. Although engrafted stem cells can differentiate into tissue cells, they also produce growth factors, including stem cell factor (SCF), macrophage colony-stimulating factor (M-CSF), SDF-1, leukemia inhibitory factor (LIF), Ang-1 and many chemokines, that intrinsically trigger tissue repair. ${ }^{22,31-33} \mathrm{HGF}$, a well-demonstrated growth 


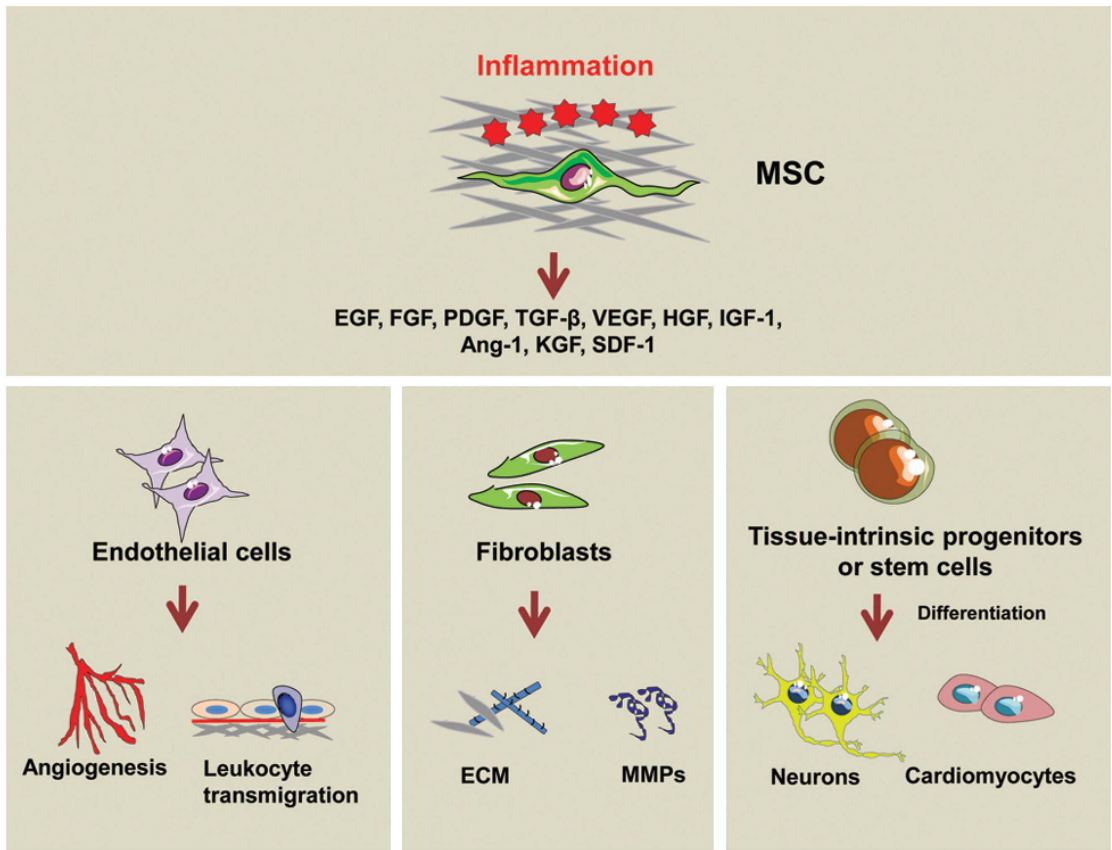

Figure 2 Tissue reparative properties of MSCs. Under the stimulation of different inflammatory cytokines at the damaged tissue sites, the newly immigrated MSCs release a plethora of growth factors, including EGF, FGF, PDGF, TGF- $\beta$, VEGF, HGF, Ang-1, KGF, SDF-1, IGF-1 and others. These growth factors orchestrate endothelial cells, fibroblasts as well as stem cells to promote tissue regeneration and repair through enhancing angiogenesis, inhibiting leukocyte transmigration and eliciting intrinsic progenitor cell/stem cell differentiation

Table 1 Summary of growth factors critical for MSC-mediated tissue repair

\begin{tabular}{|c|c|}
\hline $\begin{array}{l}\text { Growth } \\
\text { factors }\end{array}$ & Roles in MSC-mediated tissue repair \\
\hline EGF & $\begin{array}{l}\text { Wound healing }{ }_{114}^{114} \text { tissue regeneration, }{ }^{115,116} \\
\text { neurogenesis }\end{array}$ \\
\hline PDGF & Tissue repair ${ }^{118}$ \\
\hline FGF & $\begin{array}{l}\text { Tissue repair }{ }^{114} \text { intrinsic stem cell survival and } \\
\text { regeneration }\end{array}$ \\
\hline TGF- $\beta$ & Wound healing ${ }^{120,121}$ \\
\hline VEGF & Angiogenesis, wound healing ${ }^{121-123}$ \\
\hline $\begin{array}{l}\mathrm{HGF} \\
\text { IGF-1 }\end{array}$ & $\begin{array}{l}\text { Vasculogenesis, }{ }^{124} \text { intrinsic neural cell regeneration }{ }^{34} \\
\text { Wound healing, }{ }^{114} \text { neurogenesis }\end{array}$ \\
\hline KGF & Wound healing ${ }^{126}$ \\
\hline Ang-1 & Angiogenesis, tissue repair ${ }^{123}$ \\
\hline EPO & Angiogenesis 127 \\
\hline GDNF & Neuroprotective effect ${ }^{228}$ \\
\hline SDF-1 & Neuroprotective effect, ${ }^{129}$ wound healing ${ }^{130,131}$ \\
\hline IL-8 & Wound healing ${ }^{114}$ \\
\hline
\end{tabular}

Abbreviations: Ang-1, angiopoietin-1; EGF, epidermal growth factor; EPO, erythropoietin; FGF, fibroblast growth factor; GDNF, glial cell line-derived neurotrophic factor; HGF, hepatocyte growth factor; IGF, insulin growth factor-1; IL-8, interleukin-8; KGF, keratinocyte growth factor; MSC, mesenchymal stem cell; PDGF, platelet-derived growth factor; SDF-1, stem cell-derived factor-1; TGF- $\beta$, transforming growth factor $\beta$, VEGF, vascular endothelial growth factor

factor in MSC-based tissue repair, was recently shown to be effective in modulating endogenous neural cell remyelination for the enhancement of functional recovery in both experimental autoimmune encephalomyelitis (EAE) and spinal cord demyelination. ${ }^{34}$ Taken together, these observations demonstrate complex interactions that exist between MSCs and the damaged tissue during the tissue repair process. The multitude of paracrine factors produced by MSCs, which provoke tissue-resident progenitor cells or other relevant cells to initiate tissue repair, may explain the dramatic beneficial effects of MSCs on tissue repair, even in the absence of local MSC engraftment. ${ }^{34,35}$

Some tissue injuries, including those induced by chemical toxicity and trauma, are considered not immune cell-related; however, strong inflammation still occurs in these damaged tissues. ${ }^{36,37}$ Thus, better elucidation of the detailed mechanisms underlying the inflammation-modulated production of growth factors by MSCs will provide a better perspective for the clinical application of MSCs or their paracrine factors in tissue regeneration.

\section{MSCs and Inflammation Niches}

Besides the reparative functions of MSCs in inflammatory niches, the increasing evidences demonstrate that MSCs have potent immunomodulatory properties. For example, MSCs retain dendritic cells (DCs) in an immature state by inhibiting the expression of MHC class II, CD1- $\alpha$, CD40, CD80 and CD86, and by suppressing proinflammatory cytokine production. $^{38}$ TNF- $\alpha$-stimulated MSCs can recruit more monocytes/macrophages to tumor site to formulate the immunosuppressive microenvironments, thereby enhancing tumor growth. ${ }^{39}$ Moreover, MSCs induce IL-10-secreting macrophages in both in vitro and in vivo study. ${ }^{40}$ Besides DCs and macrophages, NK cells can also be suppressed by MSCs through soluble factors, such as TGF- $\beta$ and prostaglandin E2 (PGE2). ${ }^{41}$ Similar results are observed with human cells that MSCs inhibit IL-2- or IL-15-driven NK cell proliferation. ${ }^{42}$ In adaptive immune responses, MSCs have been already known to inhibit T-cell proliferation triggered by many 
types of stimuli, to downregulate IFN- $\gamma$ production and to induce Tr1 cells and Foxp $^{+}$regulatory $\mathrm{T}$ cells. ${ }^{43-45}$ In addition, they can decrease B-cell proliferation by cell-cell contact and secreted soluble factor, although the effects change dramatically according to culture conditions. ${ }^{46}$

Recently, it has been suggested that immunosuppressive functions of MSCs are triggered by the surrounding microenvironment, where abundant inflammatory factors are released from immune cells. ${ }^{4,48}$ Initially, studies of the mechanism of immune modulation by MSCs were conflicting. Some studies of graft versus host disease (GvHD) and systemic lupus erythematosus (SLE) showed the benefits of MSCs in inhibiting vigorous immune responses in vivo. ${ }^{48-50}$ In other studies, although suppression of lymphocyte proliferation by MSCs could be observed in vitro, prolongation of graft survival and rescue from GvHD in vivo were not achieved. ${ }^{51,52}$ These investigations show that the immunosuppressive property of MSCs could be affected by specific diseaserelated tissue microenvironments. It has been reported that although allogeneic MSCs are rejected by the host immune system in MHC class I- and II-mismatched recipient mice, they exhibited similar therapeutic effect on EAE as that of autologous MSCs. ${ }^{53,54}$ That is, even though MSCs have the ability to downregulate immune responses, these cells may not be immune privileged. In MSC-based therapy, the dosage of cells is also important. Using a rat brain injury model, researchers recently have found that there is an efficacy plateau, above which additional delivered MSCs could not further improve the outcome. ${ }^{55}$ Moreover, MSCs with high passage number showed diminished stem cell activation and myocardial protection. ${ }^{56}$ Hence, immunosuppression by
MSCs can be influenced by conditions, such as the source from which MSCs are isolated, the number of passages in culture before they are used, the dosages of MSCs administered and the specific pathological conditions of the recipients. Nevertheless, the immunomodulatory roles of MSCs have attracted great interest from basic and clinical researchers.

\section{Immunosuppressive Properties of MSCs}

Recently, our studies have found that the ability of MSCs to inhibit immune cell activity is licensed by inflammatory environment. IFN- $\gamma$ in combination with one of the proinflammatory cytokines, TNF- $\alpha, \mathrm{IL}-1 \alpha$ or IL- $1 \beta$, can stimulate MSCs to elicit very high levels of immunosuppressive factors, as well as a burst of chemokine and adhesion molecule expression, including CXCR3 ligands, CCR5 ligands, intercellular adhesion molecule-1 (ICAM-1) and vascular cell adhesion molecule-1 (VCAM-1). ${ }^{48,57}$ Their concerted action leads to an accumulation of immune cells in close proximity to MSCs, thus fabricating a microenvironment in which the effects of the locally acting factors produced by MSCs are amplified and leading to potent immunosuppression (Figure 3).

Surprisingly, the molecules that mediate MSC-induced immunosuppression are not the same in different species. We have found that murine MSCs use inducible nitric oxide synthase (iNOS) produced nitric oxide (NO), which is highly immunosuppressive at high concentrations through largely undefined mechanisms. ${ }^{58-60}$ In murine models of delayed-type hypersensitivity (DTH) and GvHD, when iNOS

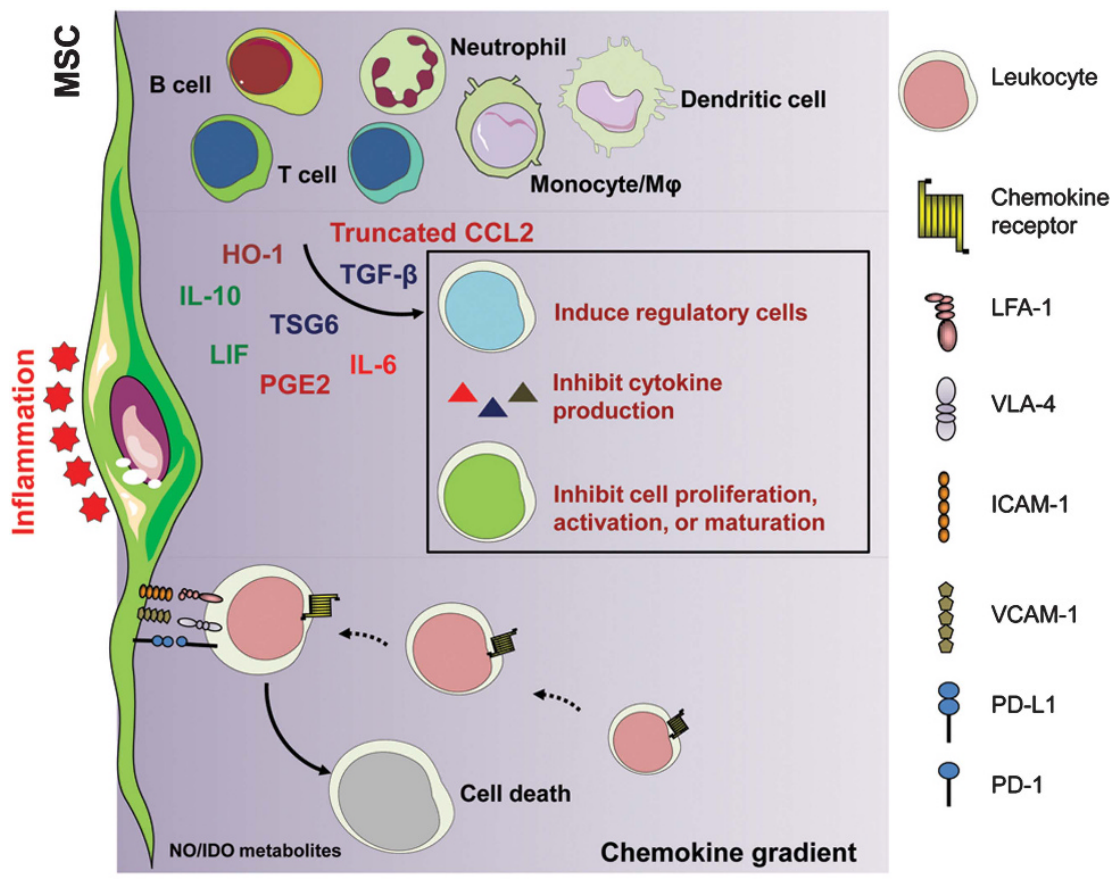

Figure 3 Immunosuppressive properties of MSCs. Damaged tissues are always accompanied by infiltration of immune cells and MSCs. Inflammation triggers the production of high levels of chemokines and adhesion molecules in MSCs, including CXCR3 ligands, CCR5 ligands, ICAM-1 and VCAM-1. These molecules induce the accumulation of immune cells in close association with MSCs, whereby high concentrations of NO (in murine MSCs) or depletion of tryptophan (in human MSCs) leads to the inhibition of immune cells. Other immunosuppressive factors such as IL-10, TSG6, IL-6, LIF, PGE2, HO-1 and truncated CCL2 could also affect immune cell activation, proliferation and functions 
activity was abolished in MSCs by either chemical inhibition or genetic ablation, the therapeutic effects disappeared. ${ }^{46,61,62}$ Meanwhile, iNOS-deficient MSCs also showed less therapeutic effects on autoimmune arthritis in mouse. ${ }^{63}$ These findings suggest that $\mathrm{NO}$ is a major player in mediating the immunosuppressive function of murine MSCs. Interestingly, metalloproteinase-mediated paracrine proteolysis of CCL2 was also found to be important in murine MSC-based therapy on EAE. ${ }^{64}$

Of note, although murine MSCs use NO to exert their immunosuppressive function, human MSCs harness indoleamine 2,3-dioxygenase (IDO) instead. ${ }^{47,65,66}$ IDO is an enzyme that catalyzes the degradation of tryptophan, an essential amino acid, along the metabolic pathway to kynurenine. Immunosuppression is believed to result from the depletion of tryptophan and the accumulation of tryptophan metabolites locally, ${ }^{67}$ but their related mechanisms have not been fully investigated. Besides IDO, tumor necrosis factor-inducible gene-6 (TSG6), a supposedly anti-inflammatory protein, can be induced in human MSCs by TNF- $\alpha$. Deletion of TSG6 in human MSCs reverses their ability to repair myocardial infarct, corneal damage and fails to prolong the corneal allograft survival. ${ }^{68-70}$ In addition, TSG6 production by human MSCs can ameliorate zymosan-induced mouse peritonitis by modulating the toll-like receptor 2 (TLR2)/nuclear factor $\kappa \mathrm{B}$ $(\mathrm{NF}-\kappa \mathrm{B})$ signaling pathway in resident macrophages. ${ }^{71} \mathrm{How}-$ ever, the exact role of TSG6 in human MSC-mediated immunoregulation merits further investigations. Other factors, such as HLA-G, LIF and some others, are also documented to mediate the immunosuppression by human MSCs in vitro ${ }^{32,72,73}$ (Table 2). LIF was found to be secreted by mouse ES cell-derived neuron progenitors and exerts the therapeutic benefit to $\mathrm{EAE}{ }^{35}$ yet the role of this molecule in murine MSC-mediated immunoregulatory effects in remains elusive.

Studies implicated that, except above mentioned immunosuppressive factors in murine or human MSCs, some molecules are shared in murine MSC- and human MSCmediated immunosuppression, such as PGE2, IL-10, hemeoxygenase-1 (HO-1), programmed cell death 1 ligand 1 (PD-L1) and IL-6 ${ }^{40,61,74-77}$ (Figure 3, Table 2). Particularly, PGE2 has been shown to be produced by inflammatory factorstimulated murine and human MSCs. PGE2 released by mouse or human MSCs alone can reprogram macrophages to produce more IL-10, inhibit DC maturation as well as shift the balance between Th1 and Th2. ${ }^{40,74,75}$ Meanwhile, it is worth noting that, in presence of PGE2, the effects of IDO in MSCmediated immunoregulation of T-cell proliferation and NK cell activation can also be enhanced. ${ }^{78,79}$ Additional studies of the mechanism of PGE2 expression in MSCs and its role in immunoregulation will be helpful for better clinical applications of MSCs. Soon after the discovery of the immunosuppressive function of MSCs, it was found that there was a clear relationship between $\mathrm{IL}-10$ and the immunosuppressive behavior of MSCs. IL-10 production was found in vivo by MSC administration or in vitro when MSCs cocultured with splenocytes. However, the role of IL-10 is still controversial. Some studies indicate that MSCs alone or with LPS/IL-3 stimulation do not secret IL-10, whereas other studies suggested that MSCs could produce high levels of IL-10 when they are cocultured with activated lymphocytes. ${ }^{80-82}$ Thus, it is obscure that the increased IL-10 production is actually from MSCs or from immune cells cocultured with MSCs. However, it has been shown that IL-10 blockade did not affect MSC-mediated immunosuppression on lymphocytes. ${ }^{83}$ Clearly, further studies should illustrate detailed mechanisms of these inhibitory factors in MSC-based immunosuppressive functions, orchestrate the network of when, where and how MSCs implement its beneficial roles in clinical applications.

The immunosuppressive property is just one facet of MSCmediated immunomodulation, however, the emerging evidence points out that MSCs can promote immune responses in the presence of low levels of inflammation, ${ }^{84}$ indicating the plasticity

Table 2 Summary of factors critical for MSC-mediated immunosuppression

\begin{tabular}{|c|c|c|}
\hline $\begin{array}{l}\text { Immunomodulatory } \\
\text { factors }\end{array}$ & Species & Roles in MSC-mediated immunosuppression \\
\hline iNOS & Murine MSCs & Inhibits T-cell proliferation $48,61,62$ \\
\hline CCL2 & Murine MSCs & Inhibits CD4 ${ }^{+}$Th17 cells $^{64}$ \\
\hline IDO & Human MSCs & $\begin{array}{l}\text { Inhibits T-cell proliferation; }{ }^{47} \text { promotes type II macrophage differentiation; }{ }^{132} \\
\text { impair NK cell activity }\end{array}$ \\
\hline Semaphorin-3A & Human MSCs & Inhibits T-cell proliferation ${ }^{133}$ \\
\hline $\mathrm{B} 7-\mathrm{H} 4$ & Human MSCs & Inhibits T-cell activation and proliferation ${ }^{134}$ \\
\hline HLA-G & Human MSCs & Inhibits PBMC response ${ }^{72,135}$ \\
\hline LIF & Human MSCs & Inhibits T-cell proliferation ${ }^{32}$ \\
\hline TSG6 & Human MSCs & Regulates macrophages, ${ }^{71}$ inhibits inflammation ${ }^{136}$ \\
\hline Galectin(s) & Human MSCs & Inhibits T-cell proliferation ${ }^{73,133}$ \\
\hline $\mathrm{HO}-1$ & Murine MSCs, human MSCs & Inhibits T-cell response; ${ }^{61}$ induces IL-10 ${ }^{+}$Tr1 and TGF-beta ${ }^{+}$Tregs $^{43}$ \\
\hline IL-6 & Murine MSCs, human MSCs & Inhibit the differentiation of dendritic cells; ${ }^{137}$ inhibit T-cell proliferation ${ }^{138}$ \\
\hline TGF- $\beta$ & Murine MSCs, human MSCs & Induces Tregs; ${ }^{139-141}$ inhibits NK cell activation and function ${ }^{41}$ \\
\hline IL-10 & Murine MSCs, human MSCs & Inhibits T-cell responses, decreases Th17 cell differentiation ${ }^{80,82,142}$ \\
\hline PGE2 & Murine MSCs, human MSCs & $\begin{array}{l}\text { Induces Foxp } 3^{+} \text {Tregs; }^{143} \text { inhibits NK cell function; }{ }^{41,79} \text { induces type II } \\
\text { macrophages; }{ }^{40,144} \text { inhibit DC maturation }\end{array}$ \\
\hline PD-L1/2 & Murine MSCs, human MSCs & Inhibits Th17 cells; ${ }^{145}$ inhibits T-cell proliferation ${ }^{146,147}$ \\
\hline FasL & Murine MSCs, human MSCs & Induces T-cell apoptosis ${ }^{76,148}$ \\
\hline
\end{tabular}

Abbreviations: CCL2, chemokine ligand 2; DC, dendritic cells; FasL, Fas ligand; HLA-G, human leukocyte antigen G; HO-1, heme oxygenase-1; IDO, indoleamine 2,3-dioxygenase; iNOS, inducible nitric oxide synthase; LIF, leukemia inhibitory factor; MSCs, mesenchymal stem cells; PGE2, prostaglandin E2; PD-L1/2, programmed cell death 1 ligand1/2; PBMC, peripheral blood mononuclear cells; TSG6, TNF- $\alpha$ stimulated gene/protein 6 


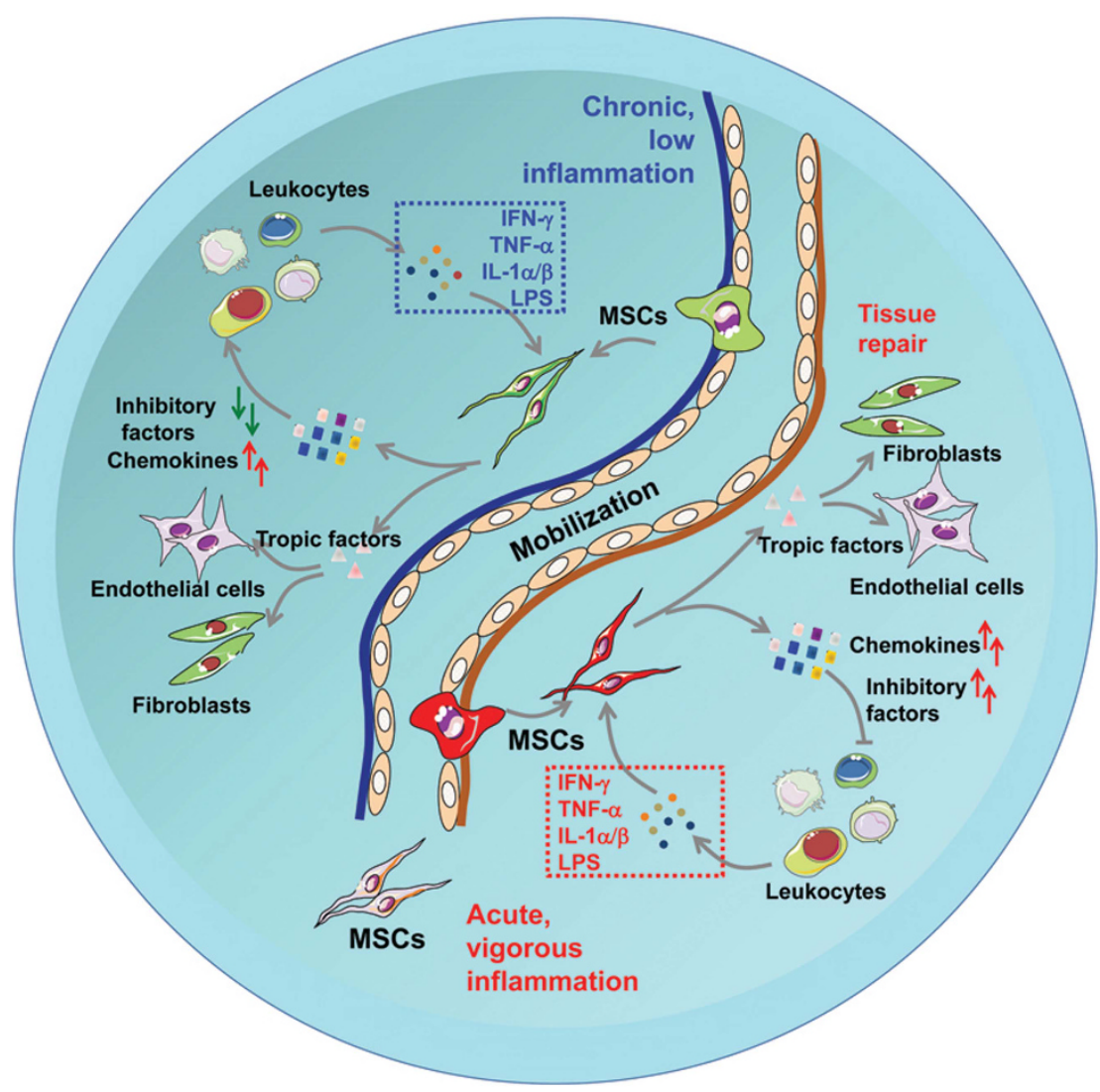

Figure 4 A proposed model of the interaction between MSCs and immune responses during tissue repair. Once tissue injury occurs, MSCs are mobilized. Vigorous inflammation licenses MSCs to possess the abilities to downregulate immune responses, a process mediated by high levels of chemokines and immune inhibitory factors. In addition, growth factors are also released by MSCs, which promote endothelial cells and mesenchymal stem/stromal cells to repair injury. Insufficient inflammatory cytokines during chronic inflammatory sites, however, could stimulate MSCs to produce chemokines and tropic factors in absence of sufficient immune inhibitory factors. As such, chronic inflammation may lead MSCs to protract the disease recovery, or even worsen the disease course

of the immunoregulatory functions of MSCs. When inflammation is low or the expression of the above mentioned immunosuppressive factors is inhibited, MSCs could dramatically promote immune responses (Figure 4). This conceptual change has significant implications for proper clinical application of MSCs.

\section{Immune Enhancing Properties of MSCs}

One of the early clinical studies of MSCs is to treat GvHD patients. ${ }^{85}$ However, the therapeutic effects are not always achieved. In some clinical trials, MSCs were ineffective in GvHD patients. In some cases, MSCs accelerated graft rejection, even coadministrated with cyclosporine $A$ (CsA). ${ }^{51,86}$ The question is why the immunosuppressive function of MSCs is not always achieved. Under certain conditions, indeed, the immunosuppressive function of MSCs does not occur, instead, an enhanced immune response is observed. For example, under inflammatory conditions rendered by high dose of concanavalin $A$ (ConA) or proinflammatory cytokines, MSCs exerted strong immunosuppressive effect. However, with low dose of ConA or the addition of IL-10, the suppressive effect of MSCs was abrogated. $^{87}$ This can also happen when the levels of inflammatory cytokines are insufficient to stimulate MSCs to secret enough NO, although still produced chemokines. ${ }^{84}$
Previous experiment also indicated that vigorous inflammation is important in eliciting the immunosuppressive function of MSCs in vivo. Less protection to GvHD was observed if MSCs were administrated at the day of bone marrow transfer. ${ }^{52}$ Good therapeutic effect can be achieved when MSCs were infused after disease development. ${ }^{48}$ Therefore, the inflammation status determines the immunomodulatory tendency of MSCs. Notably, with low dose of IFN- $\gamma$, the antigen presentation ability could be induced in MSCs. In fact, IFN- $\gamma$-stimulated MSCs can be regarded as conditional antigen presenting cells. ${ }^{88}$ Antigen-pulsed IFN- $\gamma$-treated MSCs can induce antigen-specific cytotoxic $\mathrm{CD}^{+} \mathrm{T}$ cells in vivo and thereby making MSCs candidates for the treatment of cancer or infectious diseases. ${ }^{89}$ Thus, except immunosuppressive roles, MSCs could also upregulate immune responses. Further studies on the molecular mechanisms regulating the immunoregulatory property of MSCs could have dramatic impact on the clinical application of these unique cells.

\section{Engraftment of MSCs at Sites of Injury or Inflammation}

It has been reported that trophic factors produced by MSCs can be used to implement therapeutic effects to inflammatory diseases, whereas in damaged tissue engrafted MSCs can exert concerted action, orchestrating with immune cells, 
stromal cells, endothelial cells and tissue progenitor cells to promote tissue repair. ${ }^{34,48}$ Hence, the successful engraftment of MSCs to inflammatory niches and sites of injury are important considerations when analyzing the beneficial effects of MSCs. Unlike the well-characterized phenomenon of leukocyte homing, the mechanism of MSC homing, by de novo or exogenously delivered MSCs, is still unclear. However, MSCs expressing sialyl Lewis(x), a molecule capable of promoting leukocyte migration in the inflamed tissue, exhibit higher efficiency in homing to inflamed tissues. ${ }^{90}$ It is important to note that the peripheral blood of vascular injured mice yields more MSCs than that of control mice, a finding that is likely due to enhanced levels of granulocyte colony-stimulating factor (G-CSF) following injury. ${ }^{91,92}$ Further studies are needed to lend support to the concept that injury stimulates the appearance of MSCs in the circulating blood. In addition to host MSC mobilization, more and more studies have focused on evaluating the engraftment capability and beneficial effects of exogenously delivered MSCs in animal disease models, including inflammatory bowel diseases (IBD), EAE, collagen-induced arthritis, type I diabetes and GvHD, and in clinical trials with patients suffering from GvHD, acute myocardial infarction, multiple sclerosis and Crohn's diseases. ${ }^{48,93-97}$

The therapeutic efficacy can be influenced by culture conditions, which are now known to significantly influence MSC function, because exogenously administrated MSCs always have to be expanded and passaged in vitro. It has been reported previously that extensive passages of MSCs adversely affected MSC activation and protection in ischemia/ reperfusion, a phenomenon attributed to reduced growth factor production by MSCs with high passage numbers. ${ }^{56}$ Besides, MSCs can acquire or lose certain surface receptors during culture, which might affect their chemotaxis ability. ${ }^{98}$ Indeed, compared with freshly isolated MSCs, cells maintained in culture display impaired homing ability. ${ }^{98,99}$ Related to this, CXCR4, a receptor for SDF-1that presents at high levels in the bone marrow and ischemic tissues, always disappears from the surface of MSCs after culture. However, hypoxic culture condition can promote MSC engraftment through enhancing CXCR4 and CX3CR1 expression. ${ }^{100}$ In addition, when cultured MSCs are treated with a panel of cytokines, CXCR4 level can also be recovered. This effect helps to promote the bone marrow engraftment of MSCs in irradiated NOD/SCID mice and allows easier hematological recovery of transplanted MSCs. ${ }^{101}$ Moreover, TNF- $\alpha$, TGF- $\beta$ and IL- $1 \beta$ can stimulate MSCs to secret high levels of matrix metalloproteinase, which can endow these cells the ability to migrate through extracellular matrix in response to chemokines. ${ }^{102}$ Furthermore, in in vivo study, pretreating MSCs with TNF- $\alpha$ /or a cocktail of cytokines resulted in enhanced MSC engraftment efficiency and improvement in acute pyelonephritis. ${ }^{103}$ Thus, many factors can influence MSC mobilization and engraftment. Therefore, it is critical to accurately assess and tightly control the properties of cultured MSCs for clinical application; otherwise, the physiological microenvironments they encounter may cause them to behave in unexpected ways.

Still other factors, such as injection site, timing and cell number administered, may also affect the engraftment and therapeutic effects of MSCs that are depending on the specific disease status. The various routes of injection that have been tried, including intravenous, intraperitoneal, intra-arterial and in situ, each affects the efficiency of MSC homing or localization to target organs. ${ }^{98}$ Among them, intravenous delivery is convenient and successful in treating certain type of diseases, but better engraftment efficiency can sometimes be obtained by intra-arterial and in situ injections, such as myocardial infarction, kidney transplantation and brain injury. ${ }^{104-107}$ Administration of MSCs in situ, although highly sometimes effective in both engraftment and therapy, is less clinically applicable as it is so invasive and introduces cells in a microenvironment that could be unsuitable for survival. ${ }^{108}$ In another study, in spinocerebellar ataxia, intravenous transplantation was more effective in promoting the survival of cerebellar Purkinje cells and MSC engraftment than that of intracranial injection. ${ }^{109}$ The intraperitoneal injection route has been rarely used, but some recent studies used it to treat muscular dystrophy and IBD in the mouse model, resulting in effective engraftment and therapeutic effects. ${ }^{110-112}$ Therefore, when MSCs are used to treat distinct diseases, their administration routes should be well-selected. Another influence on MSC effectiveness is the stage of disease: delivery of MSCs at an early stage following an event causing ischemia or EAE has shown enhanced engraftment rates or therapeutic effects, whereas administrated at the relapse stage of $E A E$, their beneficial effects are reduced. ${ }^{64,93,113}$ Finally, the dose of MSC administration should also be considered, because more MSC administration does not show a better therapeutic effect in the brain injury animal model. ${ }^{55}$ Taken together, these studies clearly demonstrate that when MSC-based therapies are used in preclinical experiments and clinical trials, the source of MSCs, the dose, route and timing of MSC administration should all be carefully considered.

\section{Conclusions}

We have highlighted the current understanding of the interaction between MSCs and immune responses. The differences, between murine MSCs and human MSCs, in the mechanisms mediating immunosuppression were discussed. As IDO is so central to the immunoregulatory function of human MSCs, the precise roles of tryptophan depletion and tryptophan metabolites in orchestrating such immunosuppression merit further investigation. Although MSCs disappear quickly after administration, their immunosuppressive effects linger for considerably longer. Considering that MSC supernatant alone can be effective in treating some diseases, it is possible that MSCs themselves may not be indispensable in mediating the therapeutic effect. In other words, is MSC differentiation-based repair sufficient for disease treatment, or do MSC-produced factors that modify the tissue microenvironment and lead to recovery intrinsically. Efforts of scientists in the coming years are anticipated to elucidate the precise roles of MSCs, both their reparative and immunoregulatory functions, and the mechanisms that impart and govern their clinical efficacy in the treatment of disease.

\section{Conflict of Interest}

The authors declare no conflict of interest. 
Acknowledgements. This work was supported by grants from the Ministry of Science and Technology of China (2010CB945600 and 2011DFA30630), Scientific Innovation Project of the Chinese Academy of Science (XDA 01040107 and XDA 01040110), Projects of International Cooperation and Exchanges NSFC (31010103908), the General Program of NSFC (81273316), Shanghai municipal Nature Science Foundation (12ZR1452600), the Knowledge Innovation Program of Shanghai Institutes for Biological Sciences, Chinese Academy of Sciences (2012KIP202) and Innovation Program of Shanghai Municipal Education Commission (13YZ029). We gratefully acknowledges the support of SA-SIBS Scholarship Program.

1. Uccelli A, Moretta L, Pistoia V. Mesenchymal stem cells in health and disease. Nature Rev Immunol 2008; 8: 726-762.

2. Portmann-Lanz CB, Schoeberlein A, Huber A, Sager R, Malek A, Holzgreve W et al. Placental mesenchymal stem cells as potential autologous graft for pre- and perinatal neuroregeneration. Am J Obstet and Gynecol 2006; 194: 664-673.

3. Musina RA, Belyavski AV, Tarusova OV, Solovyova EV, Sukhikh GT. Endometrial mesenchymal stem cells isolated from the menstrual blood. Bull Exp Biol Med 2008; 145 539-543.

4. Steigman SA, Fauza DO. Isolation of mesenchymal stem cells from amniotic fluid and placenta. Curr Protoc Stem Cell Biol 2007; 1: 1E.2.1-1E.2.12

5. Tirino V, Paino F, d'Aquino R, Desiderio V, De Rosa A, Papaccio G. Methods for the identification, characterization and banking of human DPSCs: current strategies and perspectives. Stem Cell Rev 2011; 7: 608-615.

6. Friedenstein AJ, Chailakhyan RK, Latsinik NV, Panasyuk AF, Keiliss-Borok IV. Stromal cells responsible for transferring the microenvironment of the hemopoietic tissues. Cloning in vitro and retransplantation in vivo. Transplantation 1974; 17: 331-340.

7. Pittenger MF, Mackay AM, Beck SC, Jaiswal RK, Douglas R, Mosca JD et al. Multilineage potential of adult human mesenchymal stem cells. Science 1999; 284 143-147.

8. De Ugarte DA, Morizono K, Elbarbary A, Alfonso Z, Zuk PA, Zhu M et al. Comparison of multi-lineage cells from human adipose tissue and bone marrow. Cells Tissues Organs 2003; 174: 101-109.

9. Mackay AM, Beck SC, Murphy JM, Barry FP, Chichester CO, Pittenger MF Chondrogenic differentiation of cultured human mesenchymal stem cells from marrow. Tissue Eng 1998; 4: 415-428.

10. Tropel P, Platet N, Platel JC, Noël D, Albrieux M, Benabid AL et al. Functional neuronal differentiation of bone marrow-derived mesenchymal stem cells. Stem Cells 2006; 24 : 2868-2876.

11. Ferrari G, Cusella-De Angelis G, Coletta M, Paolucci E, Stornaiuolo A et al. Muscle regeneration by bone marrow-derived myogenic progenitors. Science 1998 279: $1528-1530$.

12. Corselli M, Chen CW, Crisan M, Lazzari L, Péault B. Perivascular ancestors of adult multipotent stem cells. Arterioscler Thromb Vasc Biol 2010; 30: 1104-1109.

13. Crisan M, Yap S, Casteilla L, Chen CW, Corselli M, Park TS et al. A perivascular origin fo mesenchymal stem cells in multiple human organs. Cell Stem Cell 2008; 3: 301-313.

14. Hirschi KK, D'Amore PA. Pericytes in the microvasculature. Cardiovasc Res. 1996; 32 687-698

15. Tintut $Y$, Alfonso Z, Saini T, Radcliff K, Watson K, Boström K et al. Multilineage potential of cells from the artery wall. Circulation 2003; 108: 2505-2510.

16. Hoshino A, Chiba H, Nagai K, Ishii G, Ochiai A. Human vascular adventitial fibroblasts contain mesenchymal stem/progenitor cells. Biochem Biophys Res Commun 2008; 368 305-310.

17. Chidgey AP, Layton D, Trounson A, Boyd RL. Tolerance strategies for stem-cell-based therapies. Nature 2008; 453: 330-337.

18. Shi Y, Hu G, Su J, Li W, Chen Q, Shou P et al. Mesenchymal stem cells: a new strategy for immunosuppression and tissue repair. Cell Res 2010; 20: 510-518.

19. Eming SA, Krieg T, Davidson JM. Inflammation in wound repair: molecular and cellular mechanisms. J Invest Dermatol 2007; 127: 514-525.

20. Luster AD, Alon R, von Andrian UH. Immune cell migration in inflammation: present and future therapeutic targets. Nat Immunol 2005; 6: 1182-1190.

21. Krysko DV, Denecker G, Festjens N, Gabriels S, Parthoens E, D'Herde K et al. Macrophages use different internalization mechanisms to clear apoptotic and necrotic cells. Cell Death Differ 2006; 13: 2011-2022.

22. Shi $Y$, Su J, Roberts Al, Shou P, Rabson AB, Ren G. How mesenchymal stem cells interact with tissue immune responses. Trends Immunol 2012; 33: 136-143.

23. Ma XL, Liu KD, Li FC, Jiang XM, Jiang L, Li HL. Human mesenchymal stem cells increases expression of $\alpha$-tubulin and angiopoietin 1 and 2 in focal cerebral ischemia and reperfusion. Curr Neurovasc Res 2013; 10: 103-111.

24. Aguilar S, Scotton CJ, McNulty K, Nye E, Stamp G, Laurent G et al. Bone marrow stem cells expressing keratinocyte growth factor via an inducible lentivirus protects against bleomycin-induced pulmonary fibrosis. PLoS One 2009; 4: e8013.

25. Hung SP, Yang MH, Tseng KF, Lee OK. Hypoxia-induced secretion of TGF-beta 1 in mesenchymal stem cell promotes breast cancer cell progression. Cell Transplant 2012; 22: $1869-1882$.
26. Giacca M, Zacchigna S. VEGF gene therapy: therapeutic angiogenesis in the clinic and beyond. Gene Ther 2012; 19: 622-629.

27. Lee JW, Fang X, Krasnodembskaya A, Howard JP, Matthay MA. Concise review: mesenchymal stem cells for acute lung injury: role of paracrine soluble factors. Stem Cells 2011; 29: 913-919.

28. Chen L, Tredget EE, Wu PY, Wu Y. Paracrine factors of mesenchymal stem cells recruit macrophages and endothelial lineage cells and enhance wound healing. PLoS One 2008; 3: e1886.

29. Gnecchi M, He H, Liang OD, Melo LG, Morello F, Mu H et al. Paracrine action accounts for marked protection of ischemic heart by Akt-modified mesenchymal stem cells. Nat Med 2005; 11: 367-368.

30. Timmers L, Lim SK, Hoefer IE, Arslan F, Lai RC, van Oorschot AA et al. Human mesenchymal stem cell-conditioned medium improves cardiac function following myocardial infarction. Stem Cell Res 2011; 6: 206-214.

31. Van Overstraeten-Schlögel N, Beguin Y, Gothot A. Role of stromal-derived factor-1 in the hematopoietic-supporting activity of human mesenchymal stem cells. Eur J Haematol 2006; 76: 488-493.

32. Nasef A, Mazurier C, Bouchet S, François S, Chapel A, Thierry D et al. Leukemia inhibitory factor: Role in human mesenchymal stem cells mediated immunosuppression. Cell Immunol 2008; 253: 16-22.

33. Marriott MP, Emery B, Cate HS, Binder MD, Kemper D, Wu Q et al. Leukemia inhibitory factor signaling modulates both central nervous system demyelination and myelin repair. Glia 2008; 56: 686-698.

34. Bai L, Lennon DP, Caplan Al, DeChant A, Hecker J, Kranso J et al. Hepatocyte growth factor mediates mesenchymal stem cell-induced recovery in multiple sclerosis models. Nat Neurosci 2012; 15: 862-870.

35. Cao W, Yang Y, Wang Z, Liu A, Fang L, Wu F et al. Leukemia inhibitory factor inhibits T helper 17 cell differentiation and confers treatment effects of neural progenitor cell therapy in autoimmune disease. Immunity 2011; 35: 273-284.

36. Pfeifer R, Lichte P, Schreiber H, Sellei RM, Dienstknecht T, Sadeghi C et al. Models of hemorrhagic shock: differences in the physiological and inflammatory response. Cytokine 2013; 61: 585-590.

37. Liu C, Tao Q, Sun M, Wu JZ, Yang W, Jian P et al. Kupffer cells are associated with apoptosis, inflammation and fibrotic effects in hepatic fibrosis in rats. Lab Invest 2010; 90: $1805-1816$.

38. Jiang XX, Zhang Y, Liu B, Zhang SX, Wu Y, Yu XD et al. Human mesenchymal stem cells inhibit differentiation and function of monocyte-derived dendritic cells. Blood 2005; 105: 4120-4126.

39. Ren $G$, Zhao X, Wang $Y$, Zhang $X$, Chen $X, X u$ C et al. CCR2-dependent recruitment of macrophages by tumor-educated mesenchymal stromal cells promotes tumor development and is mimicked by tnFalpha. Cell Stem Cell 2012; 11: 812-824.

40. Németh K, Leelahavanichkul A, Yuen PS, Mayer B, Parmelee A, Doi K et al. Bone marrow stromal cells attenuate sepsis via prostaglandin $\mathrm{E}(2)$-dependent reprogramming of host macrophages to increase their interleukin-10 production. Nat Med 2009; 15: 42-49.

41. Sotiropoulou PA, Perez SA, Gritzapis AD, Baxevanis CN, Papamichail M. Interactions between human mesenchymal stem cells and natural killer cells. Stem Cells 2006; 24: $74-85$.

42. Spaggiari GM, Capobianco A, Becchetti S, Mingari MC, Moretta L. Mesenchymal stem cell-natural killer cell interactions: evidence that activated NK cells are capable of killing MSCs, whereas MSCs can inhibit IL-2-induced NK-cell proliferation. Blood 2006; 107: 1484-1490.

43. Mougiakakos D, Jitschin R, Johansson CC, Okita R, Kiessling R, Le Blanc K. The impact of inflammatory licensing on heme oxygenase-1-mediated induction of regulatory $T$ cells by human mesenchymal stem cells. Blood 2011; 117: 4826-4835.

44. Svobodova E, Krulova M, Zajicova A, Pokorna K, Prochazkova J, Trosan P et al. The role of mouse mesenchymal stem cells in differentiation of naive T-cells into anti-inflammatory regulatory T-cell or proinflammatory helper T-cell 17 population. Stem Cells Dev2012; 21: 901-910.

45. Krampera M, Glennie S, Dyson J, Scott D, Laylor R, Simpson E et al. Bone marrow mesenchymal stem cells inhibit the response of naive and memory antigen-specific $T$ cells to their cognate peptide. Blood 2003; 101: 3722-3729.

46. Corcione A, Benvenuto F, Ferretti E, Giunti D, Cappiello V, Cazzanti $F$ et al. Human mesenchymal stem cells modulate B-cell functions. Blood 2006; 107: 367-372.

47. Ren G, Su J, Zhang L, Zhao X, Ling W, L'Huillie A et al. Species variation in the mechanisms of mesenchymal stem cell-mediated immunosuppression. Stem Cells 2009; 27: 1954-1962.

48. Ren G, Zhang L, Zhao X, Xu G, Zhang Y, Roberts Al et al. Mesenchymal stem cellmediated immunosuppression occurs via concerted action of chemokines and nitric oxide. Cell Stem Cell 2008; 2: 141-150.

49. Le Blanc K, Frassoni F, Ball L, Locatelli F, Roelofs H, Lewis I et al. Mesenchymal stem cells for treatment of steroid-resistant, severe, acute graft-versus-host disease: a phase II study. Lancet 2008; 371: 1579-1586.

50. Sun L, Akiyama K, Zhang H, Yamaza T, Hou Y, Zhao S et al. Mesenchymal stem cell transplantation reverses multiorgan dysfunction in systemic lupus erythematosus mice and humans. Stem Cells 2009; 27: 1421-1432. 
51. Inoue S, Popp FC, Koehl GE, Piso P, Schlitt HJ, Geissler EK et al. Immunomodulatory effects of mesenchymal stem cells in a rat organ transplant model. Transplantation 2006; 81: 1589-1595.

52. Sudres M, Norol F, Trenado A, Gregoire S, Charlotte F, Levacher B et al. Bone marrow mesenchymal stem cells suppress lymphocyte proliferation in vitro but fail to prevent graftversus-host disease in mice. J Immunol 2006; 176: 7761-7767.

53. Eliopoulos N, Stagg J, Lejeune L, Pommey S, Galipeau J. Allogeneic marrow stromal cells are immune rejected by MHC class I- and class II-mismatched recipient mice. Blood 2005; 106: 4057-4065

54. Rafei M, Birman E, Forner K, Galipeau J. Allogeneic mesenchymal stem cells for treatment of experimental autoimmune encephalomyelitis. Mol Ther 2009; 17 : 1799-1803.

55. Wu J, Sun Z, Sun HS, Weisel RD, Keating A, Li ZH et al. Intravenously administered bone marrow cells migrate to damaged brain tissue and improve neural function in ischemic rats. Cell Transplant 2008; 16: 993-1005.

56. Crisostomo PR, Wang M, Wairiuko GM, Morrell ED, Terrell AM, Seshadri P et al. High passage number of stem cells adversely affects stem cell activation and myocardial protection. Shock 2006; 26: 575-580.

57. Ren G, Zhao X, Zhang L, Zhang J, L'Huillier A, Ling W et al. Inflammatory cytokine-induced intercellular adhesion molecule-1 and vascular cell adhesion molecule-1 in mesenchymal stem cells are critical for immunosuppression. $J$ Immunol 2010; 184 2321-2328.

58. Blesson S, Thiery J, Gaudin C, Stancou R, Kolb JP, Moreau JL et al. Analysis of the mechanisms of human cytotoxic $T$ lymphocyte response inhibition by NO. Int Immunol 2002; 14: 1169-1178.

59. Bogdan C. Nitric oxide and the immune response. Nat Immunol 2001; 2: 907-916

60. Staykova MA, Berven LA, Cowden WB, Willenborg DO, Crouch MF. Nitric oxide induces polarization of actin in encephalitogenic $T$ cells and inhibits their in vitro trans-endothelial migration in a p70S6 kinase-independent manner. FASEB J 2003; 17 1337-1339.

61. Chabannes D, Hill M, Merieau E, Rossignol J, Brion R, Soulillou JP et al. A role for heme oxygenase-1 in the immunosuppressive effect of adult rat and human mesenchymal stem cells. Blood 2007; 110: 3691-3694.

62. Sato K, Ozaki K, Oh I, Meguro A, Hatanaka K, Nagai T et al. Nitric oxide plays a critical role in suppression of T-cell proliferation by mesenchymal stem cells. Blood 2007; 109: 228-234.

63. Bouffi C, Bony C, Courties G, Jorgensen C, Noël D. IL-6-dependent PGE2 secretion by mesenchymal stem cells inhibits local inflammation in experimental arthritis. PLoS One 2010; 5: e14247.

64. Rafei M, Campeau PM, Aguilar-Mahecha A, Buchanan M, Williams P, Birman E et al Mesenchymal stromal cells ameliorate experimental autoimmune encephalomyelitis by inhibiting CD4 Th17 T cells in a CC chemokine ligand 2-dependent manner. J Immunol 2009; 182: 5994-6002.

65. Krampera M, Cosmi L, Angeli R, Pasini A, Liotta F, Andreini A et al. Role for interferongamma in the immunomodulatory activity of human bone marrow mesenchymal stem cells. Stem Cells 2006; 24: 386-398

66. Meisel R, Zibert A, Laryea M, Gobel U, Daubener W, Dilloo D. Human bone marrow stromal cells inhibit allogeneic T-cell responses by indoleamine 2,3-dioxygenasemediated tryptophan degradation. Blood 2004; 103: 4619-4621.

67. Mellor AL, Munn DH. IDO expression by dendritic cells: tolerance and tryptophan catabolism. Nat Rev Immunol 2004; 4: 762-774.

68. Lee RH, Pulin AA, Seo MJ, Kota DJ, Ylostalo J, Larson BL et al. Intravenous hMSCs improve myocardial infarction in mice because cells embolized in lung are activated to secrete the anti-inflammatory protein TSG-6. Cell Stem Cell 2009; 5: 54-63.

69. Oh JY, Lee RH, Yu JM, Ko JH, Lee HJ, Ko AY et al. Intravenous mesenchymal stem cells prevented rejection of allogeneic corneal transplants by aborting the early inflammatory response. Mol Ther 2012; 20: 2143-2152.

70. Roddy GW, Oh JY, Lee RH, Bartosh TJ, Ylostalo J, Coble K et al. Action at a distance: systemically administered adult stem/progenitor cells (MSCs) reduce inflammatory damage to the cornea without engraftment and primarily by secretion of TNF-alpha stimulated gene/protein 6. Stem Cells 2011; 29: 1572-1579.

71. Choi H, Lee RH, Bazhanov N, Oh JY, Prockop DJ. Anti-inflammatory protein TSG-6 secreted by activated MSCs attenuates zymosan-induced mouse peritonitis by decreasing TLR2/NF-kappaB signaling in resident macrophages. Blood 2011; 118 : 330-338.

72. Nasef A, Mathieu N, Chapel A, Frick J, François S, Mazurier $\mathrm{C}$ et al. Immunosuppressive effects of mesenchymal stem cells: involvement of HLA-G. Transplantation 2007; 84 : 231-237.

73. Gieseke F, Böhringer J, Bussolari R, Dominici M, Handgretinger R, Müller I. Human multipotent mesenchymal stromal cells use galectin-1 to inhibit immune effector cells. Blood 2010; 116: 3770-3779.

74. Aggarwal S, Pittenger MF. Human mesenchymal stem cells modulate allogeneic immune cell responses. Blood 2005; 105: 1815-1822.

75. Spaggiari GM, Abdelrazik H, Becchetti F, Moretta L. MSCs inhibit monocyte-derived DC maturation and function by selectively interfering with the generation of immature DCs: central role of MSC-derived prostaglandin E2. Blood 2009; 113: 6576-6583.
76. Gu YZ, Xue Q, Chen YJ, Yu GH, Qing MD, Shen Y et al. Different roles of PD-L1 and FasL in immunomodulation mediated by human placenta-derived mesenchymal stem cells. Hum Immunol 2013; 74: 267-276.

77. Fiorina P, Jurewicz M, Augello A, Vergani A, Dada S, La Rosa S et al. Immunomodulatory function of bone marrow-derived mesenchymal stem cells in experimental autoimmune type 1 diabetes. J Immunol 2009; 183: 993-1004.

78. Matysiak M, Orlowski W, Fortak-Michalska M, Jurewicz A, Selmaj K. Immunoregulatory function of bone marrow mesenchymal stem cells in EAE depends on their differentiation state and secretion of PGE2. J Neuroimmunol 2011; 233: 106-111.

79. Spaggiari GM, Capobianco A, Abdelrazik H, Becchetti F, Mingari MC, Moretta L. Mesenchymal stem cells inhibit natural killer-cell proliferation, cytotoxicity, and cytokine production: role of indoleamine 2,3-dioxygenase and prostaglandin E2. Blood 2008; 111 1327-1333

80. Beyth S, Borovsky Z, Mevorach D, Liebergall M, Gazit Z, Aslan H et al. Human mesenchymal stem cells alter antigen-presenting cell maturation and induce T-cell unresponsiveness. Blood 2005; 105: 2214-2219.

81. Groh ME, Maitra B, Szekely E, Koc ON. Human mesenchymal stem cells require monocyte-mediated activation to suppress alloreactive T cells. Exp Hematol 2005; 33 928-934.

82. Rasmusson I, Ringdén O, Sundberg B, Le Blanc K. Mesenchymal stem cells inhibit lymphocyte proliferation by mitogens and alloantigens by different mechanisms. Exp Cell Res 2005; 305: 33-41.

83. Xu G, Zhang L, Ren G, Yuan Z, Zhang Y, Zhao RC et al. Immunosuppressive properties of cloned bone marrow mesenchymal stem cells. Cell Res 2007; 17: 240-248.

84. Li W, Ren G, Huang Y, Su J, Han Y, Li J et al. Mesenchymal stem cells: a double-edged sword in regulating immune responses. Cell Death Differ 2012; 19 : 1505-1513.

85. Le Blanc K, Rasmusson I, Sundberg B, Gotherstrom C, Hassan M, Uzunel M et al. Treatment of severe acute graft-versus-host disease with third party haploidentical mesenchymal stem cells. Lancet 2004; 363: 1439-1441.

86. Kuo YR, Goto S, Shih HS, Wang FS, Lin CC, Wang CT et al. Mesenchymal stem cells prolong composite tissue allotransplant survival in a swine model. Transplantation 2009 87: 1769-1777.

87. Renner P, Eggenhofer E, Rosenauer A, Popp FC, Steinmann JF, Slowik P et al. Mesenchymal stem cells require a sufficient, ongoing immune response to exert their immunosuppressive function. Transplant Proc 2009; 41: 2607-2611.

88. Chan JL, Tang KC, Patel AP, Bonilla LM, Pierobon N, Ponzio NM et al. Antigenpresenting property of mesenchymal stem cells occurs during a narrow window at low levels of interferon-gamma. Blood 2006; 107: 4817-4824.

89. Romieu-Mourez R, Stock-Martineau S, Boivin MN, Bramson JL, Galipeau J. Mesenchymal stromal cells cross-present soluble exogenous antigens as part of their antigen-presenting cell properties. Blood 2009; 114: 2632-2638.

90. Sarkar D, Vemula PK, Zhao W, Gupta A, Karnik R, Karp JM. Engineered mesenchymal stem cells with self-assembled vesicles for systemic cell targeting. Biomaterials 2010; 31 5266-5274.

91. Kocher AA, Schuster MD, Szabolcs MJ, Takuma S, Burkhoff D, Wang J et al. Neovascularization of ischemic myocardium by human bone-marrow-derived angioblasts prevents cardiomyocyte apoptosis, reduces remodeling and improves cardiac function. Nat Med 2001; 7: 430-436.

92. Wang $\mathrm{CH}$, Cherng WJ, Yang NI, Kuo LT, Hsu CM, Yeh HI et al. Late-outgrowth endothelial cells attenuate intimal hyperplasia contributed by mesenchymal stem cells after vascular injury. Arterioscler Thromb Vasc Biol 2008; 28: 54-60.

93. Constantin G, Marconi S, Rossi B, Angiari S, Calderan L, Anghileri E et al. Adiposederived mesenchymal stem cells ameliorate chronic experimental autoimmune encephalomyelitis. Stem Cells 2009; 27: 2624-2635.

94. Yabana T, Arimura Y, Tanaka H, Goto A, Hosokawa M, Nagaishi K et al. Enhancing epithelial engraftment of rat mesenchymal stem cells restores epithelial barrier integrity. $J$ Pathol 2009; 218: 350-359.

95. Sutton EJ, Boddington SE, Nedopil AJ, Henning TD, Demos SG, Baehner R et al. An optical imaging method to monitor stem cell migration in a model of immune-mediated arthritis. Opt Express 2009; 17: 24403-24413.

96. Chen M, Su W, Lin X, Guo Z, Wang J, Zhang Q et al. Adoptive transfer of human gingivaderived mesenchymal stem cells ameliorates collagen-induced arthritis via suppression of Th1 and Th17 Cells and enhancement of regulatory T cell differentiation. Arthritis Rheum 2013; 65: 1181-1193.

97. Shin L, Peterson DA. Impaired therapeutic capacity of autologous stem cells in a model of type 2 diabetes. Stem Cells Transl Med 2012; 1: 125-135.

98. Karp JM, Leng Teo GS. Mesenchymal stem cell homing: the devil is in the details. Cell Stem Cell 2009; 4: 206-216.

99. Rombouts WJ, Ploemacher RE. Primary murine MSC show highly efficient homing to the bone marrow but lose homing ability following culture. Leukemia 2003; 17: 160-170.

100. Hung SC, Pochampally RR, Hsu SC, Sanchez C, Chen SC, Spees J et al. Short-term exposure of multipotent stromal cells to low oxygen increases their expression of CX3CR and CXCR4 and their engraftment in vivo. PLOS One 2007; 2: e416.

101. Shi M, Li J, Liao L, Chen B, Li B, Chen L et al. Regulation of CXCR4 expression in human mesenchymal stem cells by cytokine treatment: role in homing efficiency in NOD/SCID mice. Haematologica 2007; 92: 897-904. 
102. Sordi V, Malosio ML, Marchesi F, Mercalli A, Melzi R, Giordano T et al. Bone marrow mesenchymal stem cells express a restricted set of functionally active chemokine receptors capable of promoting migration to pancreatic islets. Blood 2005; 106: 419-427.

103. Plotnikov EY, Pulkova NV, Pevzner IB, Zorova LD, Silachev DN, Morosanova MA et al. Inflammatory pre-conditioning of mesenchymal multipotent stromal cells improves their immunomodulatory potency in acute pyelonephritis in rats. Cytotherapy 2013; 15 679-689.

104. Zonta S, De Martino M, Bedino G, Piotti G, Rampino T, Gregorini M et al. Which is the most suitable and effective route of administration for mesenchymal stem cell-based immunomodulation therapy in experimental kidney transplantation: endovenous or arterial? Transplant Proc 2010; 42: 1336-1340.

105. Freyman T, Polin G, Osman H, Crary J, Lu M, Cheng L et al. A quantitative, randomized study evaluating three methods of mesenchymal stem cell delivery following myocardial infarction. Eur Heart J 2006; 27: 1114-1122.

106. Lu D, Li Y, Wang L, Chen J, Mahmood A, Chopp M. Intraarterial administration of marrow stromal cells in a rat model of traumatic brain injury. J Neurotrauma 2001; 18: 813-819.

107. Walczak P, Zhang J, Gilad AA, Kedziorek DA, Ruiz-Cabello J, Young RG et al. Dual-modality monitoring of targeted intraarterial delivery of mesenchymal stem cells after transient ischemia. Stroke 2008; 39: 1569-1574.

108. Muschler GF, Nakamoto C, Griffith LG. Engineering principles of clinical cell-based tissue engineering. J Bone Joint Surg Am 2004; 86-A: 1541-1558.

109. Chang YK, Chen MH, Chiang YH, Chen YF, Ma WH, Tseng CY et al. Mesenchymal stem cell transplantation ameliorates motor function deterioration of spinocerebellar ataxia by rescuing cerebellar Purkinje cells. J Biomed Sci 2011; 18: 54.

110. Castelo-Branco MT, Soares ID, Lopes DV, Buongusto F, Martinusso CA, do Rosario A Jr et al. Intraperitoneal but not intravenous cryopreserved mesenchymal stromal cells home to the inflamed colon and ameliorate experimental colitis. PLOS One 2012; 7 e33360.

111. Chan J, Waddington SN, O'Donoghue K, Kurata H, Guillot PV, Gotherstrom C et al. Widespread distribution and muscle differentiation of human fetal mesenchymal stem cells after intrauterine transplantation in dystrophic mdx mouse. Stem Cells 2007; 25 : 875-884.

112. Duijvestein M, Wildenberg ME, Welling MM, Hennink S, Molendijk I, van Zuylen VL et al. Pretreatment with interferon-gamma enhances the therapeutic activity of mesenchymal stromal cells in animal models of colitis. Stem Cells 2011; 29: 1549-1558.

113. Chen J, Li Y, Wang L, Zhang Z, Lu D, Lu M et al. Therapeutic benefit of intravenous administration of bone marrow stromal cells after cerebral ischemia in rats. Stroke 2001 32: $1005-1011$.

114. Kim SW, Zhang HZ, Guo L, Kim JM, Kim MH. Amniotic mesenchymal stem cells enhance wound healing in diabetic NOD/SCID mice through high angiogenic and engraftment capabilities. PLoS One 2012; 7: e41105

115. Khalili S, Liu Y, Kornete M, Roescher N, Kodama S, Peterson A et al. Mesenchymal stromal cells improve salivary function and reduce lymphocytic infiltrates in mice with Sjögren's-like disease. PLoS One 2012; 7: e38615.

116. Yang M, Li Q, Sheng L, Li H, Weng R, Zan T. Bone marrow-derived mesenchymal stem cells transplantation accelerates tissue expansion by promoting skin regeneration during expansion. Ann Surg 2011; 253: 202-209.

117. Park HJ, Shin JY, Lee BR, Kim HO, Lee PH. Mesenchymal stem cells augment neurogenesis in the subventricular zone and enhance differentiation of neural precursor cells into dopaminergic neurons in the substantia nigra of a parkinsonian model. Cell Transplant 2012; 21: 1629-1640.

118. Chung R, Foster BK, Zannettino AC, Xian CJ. Potential roles of growth factor PDGF-BB in the bony repair of injured growth plate. Bone 2009; 44: 878-885.

119. Houchen CW, George RJ, Sturmoski MA, Cohn SM. FGF-2 enhances intestinal stem cell survival and its expression is induced after radiation injury. Am J Physiol 1999; 276: G249-G258

120. Yoon BS, Moon JH, Jun EK, Kim J, Maeng I, Kim JS et al. Secretory profiles and wound healing effects of human amniotic fluid-derived mesenchymal stem cells. Stem Cells Dev 2010; 19: 887-902

121. Hayashi $Y$, Tsuji S, Tsujii M, Nishida T, Ishii S, lijima $H$ et al. Topical implantation of mesenchymal stem cells has beneficial effects on healing of experimental colitis in rats J Pharmacol Exp Ther 2008; 326: 523-531.

122. Beckermann BM, Kallifatidis G, Groth A, Frommhold D, Apel A, Mattern J et al. VEGF expression by mesenchymal stem cells contributes to angiogenesis in pancreatic carcinoma. Br J Cancer 2008; 99: 622-631.

123. Wu Y, Chen L, Scott PG, Tredget EE. Mesenchymal stem cells enhance wound healing through differentiation and angiogenesis. Stem Cells 2007; 25: 2648-2659.

124. Kilroy GE, Foster SJ, Wu X, Ruiz J, Sherwood S, Heifetz A et al. Cytokine profile of human adipose-derived stem cells: expression of angiogenic, hematopoietic, and pro-inflammatory factors. J Cell Physiol 2007; 212: 702-709.

125. Wakabayashi K, Nagai A, Sheikh AM, Shiota Y, Narantuya D, Watanabe T et al. Transplantation of human mesenchymal stem cells promotes functional improvement and increased expression of neurotrophic factors in a rat focal cerebral ischemia model. J Neurosci Res 2010; 88: 1017-1025.

126. Kwon DS, Gao X, Liu YB, Dulchavsky DS, Danyluk AL, Bansal M et al. Treatment with bone marrow-derived stromal cells accelerates wound healing in diabetic rats. Int Wound J 2008; 5: 453-463.
127. Hou X, Wu X, Ma J, Lv X, Jin X. Erythropoietin augments the efficacy of therapeutic angiogenesis induced by allogenic bone marrow stromal cells in a rat model of limb ischemia. Mol Biol Rep 2010; 37: 1467-1475.

128. Whone AL, Kemp K, Sun M, Wilkins A, Scolding NJ. Human bone marrow mesenchymal stem cells protect catecholaminergic and serotonergic neuronal perikarya and transporter function from oxidative stress by the secretion of glial-derived neurotrophic factor. Brain Res 2012; 1431: 86-96.

129. Wang F, Yasuhara T, Shingo T, Kameda M, Tajiri N, Yuan WJ et al. Intravenous administration of mesenchymal stem cells exerts therapeutic effects on parkinsonian model of rats: focusing on neuroprotective effects of stromal cell-derived factor-1alpha. BMC Neurosci 2010; 11: 52.

130. Landry Y, Lê O, Mace KA, Restivo TE, Beauséjour CM. Secretion of SDF-1alpha by bone marrow-derived stromal cells enhances skin wound healing of C57BL/6 mice exposed to ionizing radiation. J Cell Mol Med 2010; 14: 1594-1604.

131. Li N, Lu X, Zhao X, Xiang FL, Xenocostas A, Karmazyn M et al. Endothelial nitric oxide synthase promotes bone marrow stromal cell migration to the ischemic myocardium via upregulation of stromal cell-derived factor-1alpha. Stem Cells 2009; 27: 961-970.

132. François M, Romieu-Mourez R, Li M, Galipeau J. Human MSC suppression correlates with cytokine induction of indoleamine 2,3-dioxygenase and bystander M2 macrophage differentiation. $\mathrm{Mol}$ Ther 2012; 20: 187-195.

133. Lepelletier Y, Lecourt S, Renand A, Arnulf B, Vanneaux V, Fermand JP et al. Galectin-1 and semaphorin-3A are two soluble factors conferring T-cell immunosuppression to bone marrow mesenchymal stem cell. Stem Cells Dev 2010; 19: 1075-1079.

134. Xue Q, Luan XY, Gu YZ, Wu HY, Zhang GB, Yu GH et al. The negative co-signaling molecule b7-h4 is expressed by human bone marrow-derived mesenchymal stem cells and mediates its T-cell modulatory activity. Stem Cells Dev 2010; 19: 27-38.

135. Rizzo R, Campioni D, Stignani M, Melchiorri L, Bagnara GP, Bonsi L et al. A functional role for soluble HLA-G antigens in immune modulation mediated by mesenchymal stromal cells. Cytotherapy 2008; 10: 364-375.

136. Wang $\mathrm{N}$, Li $\mathrm{Q}$, Zhang L, Lin $\mathrm{H}, \mathrm{Hu}$ J, Li $\mathrm{D}$ et al. Mesenchymal stem cells attenuate peritoneal injury through secretion of TSG-6. PLoS One 2012; 7: e43768.

137. Djouad F, Charbonnier LM, Bouffi C, Louis-Plence P, Bony C, Apparailly F et al. Mesenchymal stem cells inhibit the differentiation of dendritic cells through an interleukin6-dependent mechanism. Stem Cells 2007; 25: 2025-2032.

138. Najar M, Rouas R, Raicevic G, Boufker HI, Lewalle P, Meuleman N et al. Mesenchymal stromal cells promote or suppress the proliferation of T lymphocytes from cord blood and peripheral blood: the importance of low cell ratio and role of interleukin-6. Cytotherapy 2009; 11: 570-583.

139. Tasso R, llengo C, Quarto R, Cancedda R, Caspi RR, Pennesi G. Mesenchymal stem cells induce functionally active T-regulatory lymphocytes in a paracrine fashion and ameliorate experimental autoimmune uveitis. Invest Ophthalmol Vis Sci 2012; 53: 786-793.

140. Nemeth K, Keane-Myers A, Brown JM, Metcalfe DD, Gorham JD, Bundoc VG et al. Bone marrow stromal cells use TGF-beta to suppress allergic responses in a mouse model of ragweed-induced asthma. Proc Natl Acad Sci USA 2010; 107: 5652-5657.

141. Patel SA, Meyer JR, Greco SJ, Corcoran KE, Bryan M, Rameshwar P. Mesenchymal stem cells protect breast cancer cells through regulatory $T$ cells: role of mesenchymal stem cell-derived TGF-beta. J Immunol 2010; 184: 5885-5894.

142. Qu X, Liu X, Cheng K, Yang R, Zhao RC. Mesenchymal stem cells inhibit Th17 cell differentiation by IL-10 secretion. Exp Hematol 2012; 40: 761-770.

143. English K, Ryan JM, Tobin L, Murphy MJ, Barry FP, Mahon BP. Cell contact, prostaglandin $\mathrm{E}(2)$ and transforming growth factor beta 1 play non-redundant roles in human mesenchymal stem cell induction of $\mathrm{CD} 4+\mathrm{CD} 25$ (High) forkhead box P3 + regulatory T cells. Clin Exp Immunol 2009; 156: 149-160.

144. Ylöstalo JH, Bartosh TJ, Coble K, Prockop DJ. Human mesenchymal stem/stromal cells cultured as spheroids are self-activated to produce prostaglandin E2 that directs stimulated macrophages into an anti-inflammatory phenotype. Stem Cells 2012; 30: 2283-2296.

145. Luz-Crawford P, Noël D, Fernandez X, Khoury M, Figueroa F, Carrión $F$ et al. Mesenchymal stem cells repress Th17 molecular program through the PD-1 pathway. PLoS One 2012; 7: e45272.

146. Tipnis S, Viswanathan C, Majumdar AS. Immunosuppressive properties of human umbilical cord-derived mesenchymal stem cells: role of B7-H1 and IDO. Immunol Cell Biol 2010; 88: 795-806.

147. Sheng $H$, Wang $Y$, Jin $Y$, Zhang $Q$, Zhang $Y$, Wang $L$ et al. A critical role of IFNgamma in priming MSC-mediated suppression of T cell proliferation through up-regulation of $\mathrm{B} 7-\mathrm{H} 1$. Cell Res 2008; 18: 846-857.

148. Akiyama K, Chen C, Wang D, Xu X, Qu C, Yamaza T et al. Mesenchymal-stemcell-induced immunoregulation involves FAS-ligand-/FAS-mediated $\mathrm{T}$ cell apoptosis. Cell Stem Cell 2012; 10: 544-555.

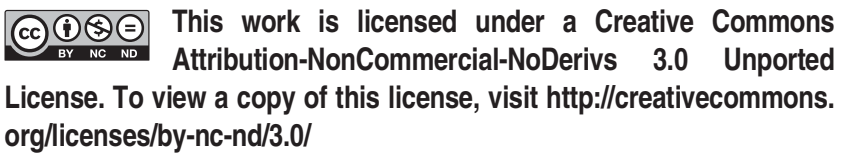

